\title{
ANALISIS FAKTOR INTERNAL DAN FAKTOR EKSTERNAL DALAM STRATEGI PENGEMBANGAN BISNIS PADA PT ESA JAYA GLOBAL
}

\author{
Elsa Dian Prastiti ${ }^{1}$, Iis Mariam ${ }^{2}$ dan Ernita Siambaton ${ }^{3}$ \\ ${ }_{1,2,3}$ Administrasi Bisnis Terapan, Politeknik Negeri Jakarta \\ Email : ${ }^{1}$ elsadianpr23@gmail.com, ${ }^{2}$ iis.mariam@yahoo.com
}

\begin{abstract}
This study aims to identify internal environmental factors, and external environmental factors that affect the company's business and formulate appropriate types of strategies that can be applied by PT Esa Jaya Global in the development of its business. The type of research used in this study is qualitative. Data collection techniques used are triangulation of three techniques, namely semistructured interviews, frank observation and documents. The source of data used consists of primary data and secondary data. Furthermore, the data was processed descriptively using EFE (External Factor Evaluation) Matrix, IFE (Internal Factor Evaluation) Matrix, SWOT Analysis Matrix, and data from the three matrices were analyzed by QSPM to determine the best and suitable strategy to be implemented in PT Esa Jaya Global . The results of this study indicate that PT Esa Jaya Global has 9 strength factors, 6 weakness factors, 2 opportunity factors, and 4 threat analyzes that affect the company. Based on the QSPM analysis, the best strategy for PT Esa Jaya Global is to conduct a work contract with customers and company partners who have the highest STAS value of 5.728 .
\end{abstract}

Key word: Logistic Expedition, EFE, IFE, SWOT, QSPM.

\begin{abstract}
Abstrak
Penelitian ini bertujuan untuk mengidentifikasi faktor lingkungan internal, dan faktor lingkungan eksternal yang mempengaruhi bisnis perusahaan serta merumuskan jenis strategi yang sesuai dan dapat diterapkan oleh PT Esa Jaya Global dalam pengembangan bisnisnya. Jenis penelitian yang digunakan dalam penelitian ini adalah kualitatif. Teknik pengumpulan data yang digunakan adalah triangulasi dari tiga teknik yaitu wawancara semi terstruktur, observasi terus terang dan dokumen. Sumber data yang digunakan terdiri dari data primer dan data sekunder. Selanjutnya data diolah secara deskriptif menggunakan Matriks EFE (External Factor Evaluation), Matriks IFE (Internal Factor Evaluation), Matriks Analisis SWOT, dan data dari ketiga matriks tersebut dianalisis dengan QSPM untuk menetapkan strategi yang paling baik dan cocok untuk diimplementasikan pada PT Esa Jaya Global. Hasil penelitian ini menunjukkan bahwa PT Esa Jaya Global memiliki 9 faktor kekuatan, 6 faktor kelemahan, 2 faktor peluang, dan 4 analisis ancaman yang berpengaruh terhadap perusahaan. Berdasarkan analisis QSPM, strategi terbaik untuk PT Esa Jaya Global adalah melakukan kontrak kerja dengan pelanggan dan mitra perusahaan yang memiliki nilai STAS tertinggi yaitu 5,728.
\end{abstract}

Kata kunci: Ekspedisi Logistik, EFE, IFE, SWOT, QSPM.

\section{PENDAHULUAN}

Jasa ekspedisi merupakan industri yang sangat berkembang pesat saat ini. Ekspedisi merupakan suatu komponen penting dalam suatu rantai distribusi. Jasa pengiriman barang di Indonesia sangat besar, namun seiring dengan penerapan pasar bebas ASEAN (MEA) menjadi sebuah tantangan bagi perusahaanperusahaan ekspedisi di tanah air untuk bisa bersaing dengan perusahaanperusahaan lain terutama dari negaranegara ASEAN sebagaimana dijelaskan oleh Subeno (2015). Menurut Asosiasi Perusahaan Jasa Pengiriman Ekspress Pos 
dan Logistik Indonesia (Asperindo) dikutip dari (Harmawan, http://id.beritasatu.com/home/optimismeusaha-jasa-kurir/167177 diakses pada 6 Maret 2018), pada kuartal pertama tahun 2017 volume jasa pengiriman telah tumbuh sekitar 14,7\% diibanding tahun 2016, terjadi peningkatan intensitas perdagangan 5,7 kali lipat.

Salah satu perusahaan yang bergerak di bidang ekspedisi logistik adalah PT Esa Jaya Global (ESA Logistic). Berdiri sejak 15 September 2014, awalnya Esa Logistic bergerak pada bidang supplier percetakan lalu Esa menjajal bisnis di bidang logistik ekspedisi yang masih berkelanjutan sampai sekarang. Esa logistic telah memiliki beberapa pelanggan yang mempercayai jasanya. Pelanggan tetap yang menggunakan jasa Esa Logistic dapat dilihat pada tabel 1 berikut.

Tabel 1 Daftar nama pelanggan Esa Logistic

\begin{tabular}{|l|l|}
\hline \multicolumn{1}{|c|}{ Nama Perusahaan } & \multicolumn{1}{|c|}{$\begin{array}{c}\text { Produk yang } \\
\text { didistribusikan }\end{array}$} \\
\hline $\begin{array}{l}\text { PT Viva Tehnik } \\
\text { Mandiri (Kenmaster } \\
\text { Indonesia) }\end{array}$ & $\begin{array}{l}\text { Regulator gas, } \\
\text { kompor gas, spons }\end{array}$ \\
\hline PT Sepanjang Aneka & $\begin{array}{l}\text { Rak pajang } \\
\text { kosmetik Pond's }\end{array}$ \\
\hline $\begin{array}{l}\text { PT Multi Bintang } \\
\text { Indonesia (Bir } \\
\text { Bintang) }\end{array}$ & $\begin{array}{l}\text { Kulkas, karpet, } \\
\text { lampu }\end{array}$ \\
\hline
\end{tabular}

Sumber: PT Esa Jaya Global, 2018

Berdasarkan tabel 1 di atas, pengguna jasa Esa Logistic adalah perusahaanperusahaan atau distributor serta konsumen lain yang ingin mengirimkan barangnya dengan cepat dan aman. Keberhasilan usaha jasa ekspedisi sangat bergantung pada pelayanan dan ketepatan waktu juga tarif sehingga dapat dipercaya oleh para konsumen sehingga konsumen puas dan loyal.

Perusahaan didirikan dengan berbagai tujuan pokok dan untuk mencapai tujuan tersebut manajemen perlu memperhatikan dua faktor pokok yakni faktor eksternal dan internal. Tujuan ESA logistic saat ini adalah menjadi penyedia jasa logistik ekspedisi yang memiliki cabang perusahaan di banyak daerah disertai dengan gudang yang luas. Untuk mencapai tujuan tersebut ESA tentunya harus merancang strategi untuk dapat bersaing dengan perusahaan sejenis lainnya yang telah memiliki nama besar. Strategi dapat disusun dengan memperhatikan faktor pokok dan terlebih dahulu menganalisis kekurangan dan kelebihan perusahaan. Proses pengambilan keputusan perencanaan strategis selalu berkaitan dengan pengembangan misi, tujuan, strategi dan kebijakan perusahaan. Hampir setiap perusahaan maupun pengamat bisnis dalam pendekatannya banyak menggunakan analisis SWOT.

Berdasarkan uraian yang telah dijelaskan di atas, penulis tertarik untuk melakukan penelitian dengan tujuan mengetahui bagaimana strategi yang dapat dilakukan oleh PT Esa Jaya Global dalam pengembangan usahanya, dengan demikian penulis memilih judul skripsi yaitu "Analisis Faktor Internal dan Faktor Eksternal dalam Strategi Pengembangan Bisnis pada PT Esa Jaya Global.”

\section{Rumusan Masalah}

Rumusan masalah pada penelitian ini adalah "Apa saja faktor lingkungan internal yang mempengaruhi usaha ekspedisi PT Esa Jaya Global?” lalu, “Apa saja faktor lingkungan eksternal yang mempengaruhi usaha ekspedisi PT Esa Jaya Global" dan "Jenis strategi yang bagaimana yang sesuai dan dapat dilakukan PT Esa Jaya Global dalam pengembangan usahanya?”

\section{Tinjauan Pustaka \\ Strategi}

"Strategi adalah tindakan potensial yang membutuhkan keputusan manajemen puncak dan sumber daya perusahaan dalam jumlah yang besar." (David dan David, 2016:11). Porter dalam Nilasari (2016:3) menyatakan bahwa strategi adalah penciptaan posisi unik dan berharga yang didapatkan dengan melakukan serangkaian 
aktivitas yang tidak dilakukan oleh pesaing atau lawan.

\section{Manajemen Strategi}

David dan David (2016:3) mendefinisikan manajemen strategi sebagai seni dan ilmu merumuskan, mengimplementasi, dan mengevaluasi keputusan lintas fungsional untuk mencapai tujuannya. Manajemen strategi terdiri atas tiga tahapan, yaitu: formulasi strategi, implementasi strategi, dan evaluasi strategi

Menurut David (2013:45) manfaat manajemen strategis adalah untuk membantu organisasi merumuskan strategi-strategi yang lebih baik melalui penggunaan pendekatan terhadap pilihan strategi yang lebih sistematis, logis dan rasional.

\section{Analisis Lingkungan}

Menurut Purnomo dan Zulkieflimansyah (2007:15) analisis lingkungan adalah proses awal dalam manajemen strategi yang bertujuan untuk memantau lingkungan perusahaan baik internal maupun eksternal yang dapat mempengaruhi pencapaian tujuan.

Menurut David dan David (2016:81) proses audit internal mensyaratkan pengumpulan informasi mengenai manajemen, pemasaran, keuangan dan akuntansi, produksi, dan operasi, R\&D serta Sim perusahaan. Sedangkan audit eksternal berfokus mengidentifikasi dan mengevaluasi tren dan kejadian di luar kendali perusahaan. Indikator lingkungan eksternal terbagi menjadi lima kategori yaitu ekonomi, budaya sosial demografi dan lingkungan, politik pemerintah dan hukum, kekuatan teknologi, dan kekuatan persaingan.

\section{Analisis SWOT}

Menurut Rangkuti (2014:18) analisis SWOT adalah identifikasi berbagai faktor secara sistematis untuk merumuskan strategi perusahaan,. Analisis ini didasarkan pada logika yang dapat memaksimalkan kekuatan dan peluang, namun secara bersamaan dapat meminimalkan kelemahan dan ancaman.

\section{QSPM}

Menurut David dan David (2016:184) Quantitative Strategic Planning Matrix merupakan satu teknik analitits dalam literature yang didesain utnuk menentukan daya tarik relatif dari tindakan altenatif yang layak. QSPM merupakan alat yang memungkinkan penyusun strategi mengevaluasi faktor kunci.

\section{HASIL DAN PEMBAHASAN}

Penelitian ini dilaksanakan dengan menggunakan metode deksriptif kualitatif dengan tujuan untuk mendeskripsikan atau mengambarkan apa adanya mengenai masalah yang ditemui dalam perusahaan melalui wawancara dengan sumber terpercaya (informan penelitian).

\section{Informan Penelitian}

Informan dalam penelitian ini dipilih secara purposive sampling. Informan dipilih berdasarkan pengetahuan mendalam tentang perusahaan. Informan dalam penelitian ini yaitu Direktur, Manajer Operasional, dan Manajer Pemasaran.

\section{Teknik Pengumpulan Data}

Dalam penelitian ini, pengumpulan data dilakukan dengan menggunakan teknik Triangulasi dari tiga teknik yaitu wawancara semi-terstruktur, observasi terus terang dan dokumen. serta melalui kajian pustaka.

\section{Teknik Pengolahan Data}

Metode pengolahan data dilakukan secara deskriptif dengan pertimbangan adanya kesediaan dari pemilik perusahaan untuk menganalisis kondisi perusahaan selanjutnya merumuskan pengembangan strategi perusahaan dengan menggunakan matriks IFE (Internal Factor Evaluation), matirk EFE (External Factor Evaluation), 
SWOT dan QSPM untuk menemukan alternatif strategi.

\section{Teknik Analisis Data}

Teknik analisis data yang digunakan dalam penelitian ini adalah teknik analisis kualititatif model Miles dan Huberman. Menurut Miles dan Huberman (1984) dalam Sugiyono (2017:247) aktivitas dalam analisis data yaitu Data Reduction (Reduksi Data), Data Display (Penyajian Data) dan Conclusing Drawing/Verification.

Pembahasan yang dihasilkan dari pengumpulan, pengolahan dan analisis data yang telah dilakukan adalah sebagai berikut:

a. Analisis Faktor Internal

Berdasarkan hasil wawancara yang dilakukan kepada tiga informan yaitu Direktur, Manajer Operasional, dan Manajer Pemasaran PT Esa Jaya Global, menghasilkan faktor internal yang dibutuhkan dalam analisis strategi pengembangan bisnis, yaitu terdiri atas kekuatan dan kelemahan antara lain:

1) Analisis Kekuatan

Kekuatan adalah kondisi yang merupakan gambaran kemampuan perusahaan saat ini yang dapat memberi keuntungan untuk dapat bersaing dengan perusahaan sejenis lainnya. Esa Logistik memiliki kekuatan sebagai berikut:

a) Armada yang cukup untuk menunjang kegiatan ekspedisi

Armada atau kendaraan adalah aset utama suatu perusahaan ekspedisi logistik. Esa Logistik merasa sudah cukup atas armada transportasi yang dimiliki perusahaan saat ini karena selama ini order dari pelanggan dapat ditangani dengan baik sesuai kapasitas perusahaan.

b) SOP yang telah berjalan baik

SOP sangat penting bagi sebuah perusahaan agar dapat mengantisipasi berbagai situasi yang mungkin terjadi. SOP yang ada dalam Esa Logistik meliputi berbagai bidang pekerjaan di dalamnya yaitu SOP dalam menangani pelanggan, SOP penanganan barang, SOP keuangan dan lain sebagainya.

c) Layanan berkualitas dengan harga terjangkau

Pelayanan berkualitas adalah salah satu hal yang wajib dimiliki suatu perusahaan jasa. Untuk dapat menunjang kualitas terbaik untuk para konsumen, perusahaan menetapkan harga terjangkau dan sesuai dengan pelayanan yang diberikan.

d) Perusahaan dapat menyesuaikan layanan dengan kebutuhan pelanggan

Esa Logistik menawarkan layanan sesuai dengan keinginan pelanggan misalnya, ketika pelanggan butuh untuk melakukan pick up barang dimalam hari atau dinihari dengan request sebelumnya, maka Esa Logistik dapat melayani kebutuhan tersebut.

e) Modal yang memadai

Modal merupakan hal penting dalam suatu perusahaan agar kegiatan perusahaan tersebut dapat berjalan dengan baik. Tanpa adanya modal, kegiatan perusahaan dapat sangat terganggu. Modal Esa Logistik saat ini masih terbilang aman dan tidak kekurangan dana.

f) Memiliki beberapa pelanggan setia

Walaupun baru beberapa tahun terjun ke dalam bisnis ekspedisi logistik, Esa Logistik sudah memiliki beberapa pelanggan yang setia menggunakan jasanya yaitu PT Viva Tehnik Mandiri, PT Sepanjang Aneka, PT Multi Bintang Indonesia dan lain sebagainya.

g) Layanan update report yang akurat

Esa Logistik selalu memberikan data reporting terkait barang yang dikirim kepada para pelanggan yang menggunakan jasanya. Data tersebut dikirimkan melalui email dalam bentuk worksheet excel karena biasanya barang yang dikirim berjumlah banyak. 
h) Memiliki website yang mudah diakses

Website dibuat agar calon pelanggan dapat mengetahui berbagai informasi perusahaan. Perusahaan yang memiliki website biasanya dipandang lebih profesional. Website Esa Logistik dapat diakses

pada

www.esalogisticsindo.com

i) Mampu menjaga hubungan baik dengan pelanggan dan mitra

Pelanggan merupakan aset berharga perusahaan. Hubungan baik dengan pelanggan harus selalu dijaga demi berjalannya kegiatan perusahaan, oleh karena itu Esa Logistik sangat menghargai hubungan dengan pelanggan maupun mitra di daerah.

2) Analisis Kelemahan

a) Promosi masih melalui mulut ke mulut

Esa Logistik saat ini masih bergantung pada promosi melalui mulut ke mulutu dan belum menggunakan media promosi lain yang jauh lebih efektif.

b) Jumlah SDM yang masih terbatas dan belum banyak pengalaman

Jumlah SDM pada PT Esa Logistik yang masih terhitung sedikit seringkali membuat pekerjaan tumpang tindih. Selain itu, ada beberapa SDM yang masih berlatar lulusan SMA/SMK yang belum berpengalaman.

c) Manajemen belum memiliki fasilitas pengembangan dan pelatihan karyawan

Esa Logistik belum pernah melakukan pelatihan dan pengembangan karyawan. Hal tersebut perlu dilakukan untuk menunjang kinerja karyawan yang berdampak pada keunggulan perusahaan.

d) Perusahaan masih terbilang baru

Dibanding para pesaing yang jauh lebih dulu terjun dalam bisnis ekspedisi logistik, Esa Logistik masih belum dikenal seperti para pesaingnya sehingga masih kurang dalam hal jumlah pelanggan dan relasi bisnis. e) Masih sering terjadi kelalaian saat pengiriman barang

Barang yang dititipkan pelanggan untuk dikirimkan oleh Esa Logistik jumlahnya tidak sedikit, serta jenis barang dan penanganannya yang berbeda pula. Kendala yang sering dihadapi Esa Logistik salah satunya adalah barang masih sering rusak atau hilang sehingga menimbulkan kesalahpahaman antara perusahaan dengan pelanggan.

f) Keterbatasan gudang jika sedang high season

Barang yang telah di pick up dari pelanggan harus segera didistribusikan ke tempat tujuannya masing-masing. Barang tersebut perlu dilakukan packing sebelumnya di gudang Esa Logistik. Namun, gudang yang dimiliki Esa Logistik seringkali tidak cukup untuk menampung barang pelanggan, terlebih ketika pesanan sedang pada masa high season.

Berdasarkan penjelasan indikator faktor internal, serta kuesioner mengenai faktor internal, skor IFE yang didapat sebesar 2.89. Merujuk pada teori (Rangkuti, 2014) skor tersebut menghasilkan bahwa PT Esa Jaya Global dapat dikatakan memiliki posisi yang kuat dalam bisnis dilihat dari faktor-faktor internal di atas. Faktor kekuatan dengan skor tertinggi yaitu 0.327 diduduki oleh dua indikator secara bersamaan yaitu armada yang cukup untuk menunjang kegiatan ekspedisi dan update report yang akurat. Sedangkan faktor kelemahan dengan skor terendah yaitu 0.049 adalah promosi yang masih mengandalkan mulut ke mulut.

\section{b. Analisis Faktor Eksternal}

1) Analisis Peluang

Peluang adalah suatu situasi yang menggambarkan kesempatan yang ada dari sisi luar organisasi tersebut. Adapun peluang dalam Esa Logistik adalah sebagai berikut: 
a) Pangsa pasar yang luas

Bisnis logistik ekspedisi mempunyai pangsa pasar yang luas karena segala bentuk bisnis pasti memerlukan jasa logistik ekspedisi untuk mengirim barang-barangnya.

b) Dapat mengambil alih pekerjaan apabila pesaing mengalami overload Banyak pesaing Esa Logistik dalam bidang sejenis yang terkadang tidak mampu menghandle pekerjaan yang melebihi kapasitas pengiriman mereka. Dalam hal ini Esa Logistik memanfaatkan peluang untuk mengambil alih pekerjaan tersebut.

2) Analisis Ancaman

Ancaman merupakan suatu keadaan yang dapat berpotensi melemahkan perusahaan. Ancaman pada PT Esa Logistik yaitu:

a) Adanya pesaing dengan armada transportasi lebih lengkap

Pesaing dengan jumlah armada transportasi lebih lengkap dapat menjadi ancaman untuk Esa Logistik yang masih memiliki armada yang masih terbatas. Hal ini dapat mempengaruhi kapasitas pengiriman barang oleh Esa Logistik.

b) Pesaing multinasional dengan harga lebih murah

Banyaknya perusahaan asing yang membuka cabang di Indonesia dengan layanan yang lebih lengkap dan harga lebih kompetitif membuat hal tersebut termasuk dalam ancaman untuk Esa Logistik.

c) Munculnya ekspedisi baru yang dibuat oleh perusahaan ritel

Ada beberapa perusahaan ritel berbasis platform online tersebut membuat jasa ekspedisinya sendiri dalam rangka menghemat biaya pengantaran. Perusahaan ritel tersebut sebelumnya sering menggunakan jasa Esa Logistik, namun karena telah memiliki jasa ekspedisi sendiri, perusahaan tersebut otomatis tidak akan kembali menggunakan jasa Esa Logistik. d) Terkadang distribusi terkendala cuaca yang sulit ditebak

Distribusi yang dilakukan Esa Logistik tidak hanya mencakup domestik saja namun juga ke luar daerah di seluruh Indonesia. Cuaca antara daerah satu dengan lainnya seringkali berbeda jauh. Cuaca dapat menjadi sebuah kendala yang sangat kompleks dalam pendistribusian barang.

Berdasarkan penjelasan indikator faktor internal, serta kuesioner mengenai faktor internal, skor IFE yang didapat sebesar 2.06. Merujuk pada (Rangkuti, 2014) skor tersebut mengindikasikan posisi PT Esa Jaya Global memiliki peluang yang kecil serta ancaman yang kuat dalam bisnisnya. Faktor peluang dengan skor tertinggi yaitu 0.628 adalah pangsa pasar yang luas. Sedangkan faktor ancaman dengan skor terendah yaitu 0.193 adalah adanya pesaing dengan transportasi lebih lengkap.

c. Analisis Matriks SWOT

Berdasarkan analisis lingkungan internal dan eksternal, dapat diidentifikasikan empat faktor kekuatan, kelemahan, peluang dan ancaman PT Esa Jaya Global yang dapat dilihat pada tabel 2.

Tabel 2. Analisis SWOT PT Esa Jaya Global

\begin{tabular}{|c|c|}
\hline Strengths: & Weaknesses: \\
\hline 1. Armada yang cukup & 1. Promosi masih \\
\hline untuk menunjang & mengandalkan \\
\hline kegiatan ekspedisi & melalui mulut ke \\
\hline 2. Memiliki SOP yang & mulut \\
\hline telah berjalan baik & 2. Jumlah SDM \\
\hline 3. Layanan berkualitas & terbatas \\
\hline $\begin{array}{l}\text { dengan } \quad \text { harga } \\
\text { terjangkau }\end{array}$ & $\begin{array}{l}\text { dan belum } \\
\text { banyak }\end{array}$ \\
\hline 4. Dapat & pengalaman \\
\hline menyesuaikan & 3. Manajemen \\
\hline $\begin{array}{l}\text { layanan dengan } \\
\text { kebutuhan } \\
\text { pelanggan }\end{array}$ & $\begin{array}{l}\text { belum memiliki } \\
\text { fasilitas } \\
\text { pengembangan }\end{array}$ \\
\hline $\begin{array}{l}\text { 5. Modal yang } \\
\text { memadai }\end{array}$ & $\begin{array}{l}\text { dan pelatihan } \\
\text { karyawan }\end{array}$ \\
\hline $\begin{array}{l}\text { 6. Memiliki beberapa } \\
\text { pelanggan setia }\end{array}$ & $\begin{array}{l}\text { 4. Perusahaan masih } \\
\text { terbilang baru }\end{array}$ \\
\hline 7. Layanan update & dalam bisnis \\
\hline report yang akurat & ekspedisi logistik \\
\hline $\begin{array}{l}\text { 8. Website yang } \\
\text { mudah diakses }\end{array}$ & $\begin{array}{l}\text { 5. Masih } \\
\text { terjadi } \\
\text { kelalaian }\end{array}$ \\
\hline
\end{tabular}




\begin{tabular}{|c|c|}
\hline $\begin{array}{l}\text { 9. } \begin{array}{lr}\text { Mampu menjaga } \\
\text { hubungan } & \text { baik } \\
\text { dengan pelanggan } \\
\text { dan mitra }\end{array}\end{array}$ & $\begin{array}{l}\text { saat pengiriman } \\
\text { barang } \\
\text { 6. Keterbatasan } \\
\text { gudang jika } \\
\text { dalam masa high } \\
\text { season }\end{array}$ \\
\hline $\begin{array}{l}\text { Opportunities: } \\
\text { 1. Pangsa pasar yang } \\
\text { luas } \\
\text { 2. Dapat mengambil } \\
\text { alih pekerjaan } \\
\text { apabila pesaing } \\
\text { mengalami } \\
\text { overload }\end{array}$ & $\begin{array}{l}\text { Threats: } \\
\text { 1. Pesaing dengan } \\
\text { armada } \\
\text { transportasi lebih } \\
\text { lengkap } \\
\text { 2. Pesaing } \\
\text { multinasional } \\
\text { dengan harga } \\
\text { lebih murah } \\
\text { 3. Munculnya } \\
\text { perusahaan } \\
\text { ekspedisi baru } \\
\text { yang dibuat } \\
\text { 4erkadang } \\
\text { distribusi } \\
\text { terkendala cuaca } \\
\text { yang tidak bisa } \\
\text { ditebak }\end{array}$ \\
\hline
\end{tabular}

Sumber: Data primer diolah, 2018

Berdasarkan hasil analisis Matriks SWOT Esa Logistik maka diperoleh tiga strategi SO, tiga strategi WO, tiga strategi ST, dan dua strategi WT yang dapat dilihat pada tabel 3.

\section{Tabel 3. Matriks Analisis SWOT}

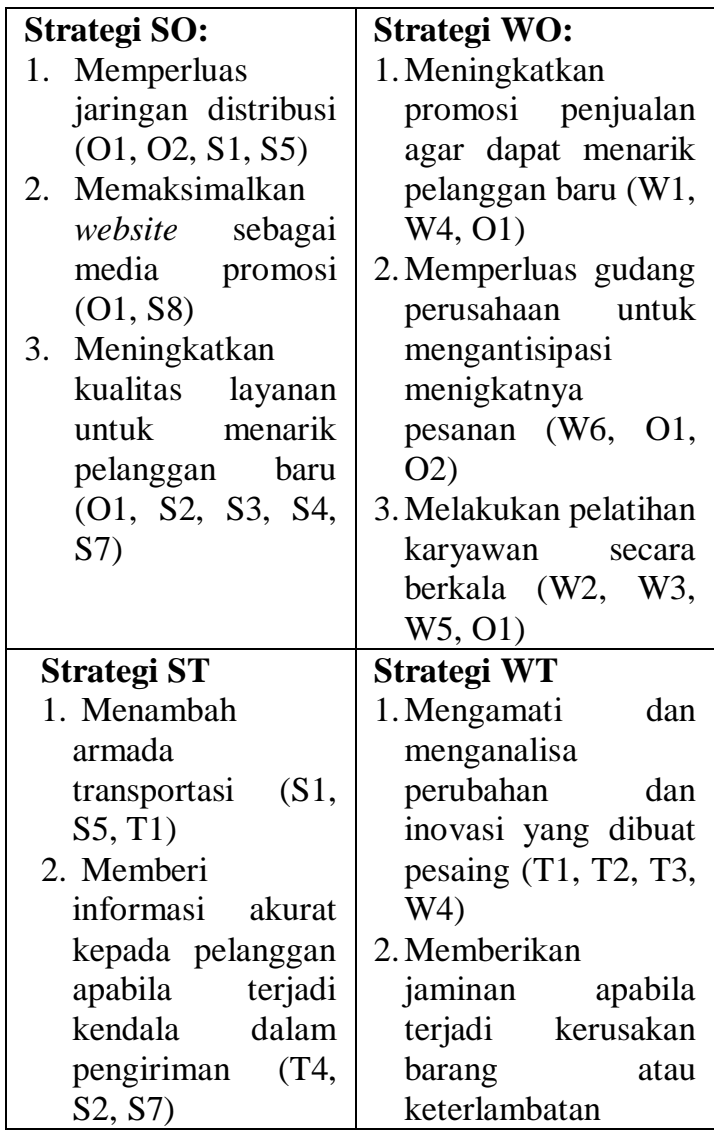

\begin{tabular}{|l|l|}
\hline 3. Membuat kontrak & pengiriman (W5, T3, \\
kerja dalam waktu & T4) \\
tertentu dengan & \\
pelanggan dan & \\
mitra ( T2, T3, S6, & \\
S9) & \\
\hline
\end{tabular}

Sumber: Data primer diolah, 2018

Berdasarkan analisis matriks SWOT didapatkan beberapa alternatif strategi yaitu:

\section{1) Alternatif Strategi SO}

Alternatif strategi SO adalah strategi yang dibuat dengan memanfaatkan kekuatan perusahaan untuk mencapai peluang sebesar-besarnya. Berikut adalah alternatif strategi SO pada PT Esa Jaya Global.

\section{a) Memperluas jaringan distribusi}

Faktor-faktor peluang O1, dan $\mathrm{O} 2$ mengindikasikan peluang bahwa pangsa pasar untuk bidang ekspedisi logistik sangatlah luas. Selain itu, perusahaan memiliki peluang untuk dapat mengambil alih pekerjaan dikala pesaing sedang mengalami overload. Perusahaan dapat menangkap peluangpeluang tersebut menggunakan faktorfaktor kekuatan yang dimiliki yaitu S1, dan S5. Alternatif strategi yang dapat digunakan adalah memperluas jaringan distribusi..

b) Memaksimalkan website sebagai media promosi

Berdasarkan luasnya pangsa pasar bisnis ekspedisi logistik (O1) pada dasarnya perusahaan memiliki banyak calon pelanggan yang berpotensi menggunakan jasanya. Alternatif strategi yang dibentuk adalah memaksimalkan website sebagai bentuk promosi, strategi ini diperkuat oleh indikator S8 yaitu perusahaan sudah memiliki website yang mudah diakses.

c) Meningkatkan kualitas layanan untuk mendapat pelanggan baru

Jasa ekspedisi logistik yang sangat dibutuhkan membuat pangsa pasar bisnis tersebut menjadi sangat luas (O1) hal tersebut dapat membuat perusahaan berpotensi memiliki banyak pelanggan. Strategi yang dapat dilakukan untuk 
merealisasikan potensi tersebut adalah dengan meningkatkan kualitas layanan demi menarik pelanggan baru. Kualitas layanan dapat ditingkatkan dengan mengoptimalkan layanan yang sudah dimiliki perusahaan saat ini yaitu layanan berkualitas dengan harga terjangkau (S3), layanan update report yang akurat (S7) serta dapat menyesuaikan layanan dengan keinginan pelanggan (S4). Hal ini tentunya didukung oleh SOP yang dilaksanakan dengan baik (S2).

2) Alternatif Strategi WO

1) Meningkatkan promosi penjualan untuk menarik pelanggan baru

Esa Logistik yang baru beberapa tahun terjun ke dalam bisnis ekspedisi logistik (W4) sangat mengandalkan promosi melalui mulut ke mulut dari pelanggan (W1). Alternatif strategi yang dapat dilakukan adalah dengan meningkatkan promosi penjualan terutama dengan menggunakan media yang lain serta dengan memanfaatkan peluang yang ada saat ini, yaitu pangsa pasar yang luas (O1), dengan begitu perusahaan berpotensi mendapat pelanggan baru dan keuntungan lebih.

2) Memperluas gudang perusahaan untuk mengantisipasi meningkatnya pesanan

Dengan melihat peluang yang ada terkait luasnya pangsa pasar (O1), suatu perusahaan dalam bidang logistik harus memiliki gudang yang cukup untuk menampung barang-barang pelanggan yang akan didistribusikan ke tujuannya masing-masing. Terlebih adanya peluang perusahaan untuk dapat mengambil alih pekerjaan pesaing jika pesaing mengalami overload (O2), hal tersebut tentu saja dapat berpotensi menarik lebih banyak pelanggan sehingga barang-barang pelanggan bisa lebih banyak lagi jumlahnya. Alternatif strategi yang dapat dilakukan adalah dengan memperluas gudang perusahaan untuk mengantisipasi barang pelanggan yang melebihi kapasitas gudang.
3) Melakukan pelatihan karyawan secara berkala

Karyawan yang ada di Esa Logistik dapat dikatakan masih kurang berkompeten karena perekrutan karyawan lebih mengutamakan skill namun tidak begitu mementingkan latar belakang pendidikannya (W2). Selain itu masih sering terjadi kelalaian yang dilakukan oleh karyawan terkait barang-barang pelanggan antara lain kerusakan atau kehilangan (W5). Melihat adanya pangsa pasar yang luas untuk jasa ekspedisi logistik (O1), perusahaan perlu mengambil alternatif strategi yaitu melakukan pelatihan untuk para karyawan secara berkala. Terlebih lagi, perusahaan belum pernah dan tidak memiliki fasilitas untuk pelatihan dan pengembangan karyawan (W3). Dengan adanya pelatihan dan pengembangan karyawan, diharapkan kelalaian atas barang pelanggan dapat berkurang serta dapat meningkatkan kinerja perusahaan.

3) Alternatif Strategi ST

1) Menambah armada transportasi

Armada yang dimiliki Esa logistik saat ini sebenarnya masih mencukupi kapasitas pesanan yang diterima saat ini (S1) namun jika dibanding pesaing, kendaraan yang dimiliki Esa Logistik masih sangat terbatas, karena pesaing memiliki armada dengan berbagai jenis ukuran dan jumlahnya banyak (T1). Alternatif strategi yang dapat dilakukan adalah dengan menambah armada perusahaan. Hal ini dapat ditunjang dengan modal perusahaan yang memadai (S5). Dengan bertambahnya armada, dapat mengantisipasi pesanan yang sewaktu-waktu mengalami overload.

2) Memberi informasi akurat kepada pelanggan apabila terjadi kendala dalam pengiriman

Pengiriman yang cepat merupakan harapan pelanggan yang menggunakan jasa ekspedisi. Namun pada kenyataannya, akan selalu ada kendala 
dalam pendistribusian barang, misalnya kendala terkait cuaca (T4), cuaca yang sulit ditebak dapat memperlambat estimasi pengiriman barang. Alternatif strategi yang dapat dilakukan untuk mengatasi masalah tersebut adalah memberi informasi terkait kendala yang dialami dalam proses pendistribusian barang. Strategi ini sesuai dengan prinsip perusahan sebelumnya yaitu memberikan data reporting yang akurat terkait barang pelanggan (S7). Hal ini juga menyesuaikan SOP perusahaan yang saat ini ssudah berjalan dengan baik (S2).

3) Membuat kontrak kerja dalam waktu tertentu dengan pelanggan dan mitra Banyaknya perusahaan sejenis yang baru lahir (T3) serta banyaknya perusahaan multinasional yang menawarkan harga lebih rendah (T2) merupakan sebuah ancaman karena pelanggan dapat sewaktu-waktu berpindah ke perusahaan pesaing. Dalam menghadapi ancaman tersebut, alternatif strategi yang dapat dilakukan adalah dengan membuat kontrak kerja dalam waktu tertentu untuk menjalin kerjasama dengan para mitra serta pelanggan perusahaan. Strategi ini tentunya memanfatkan kekuatan perusahaan yaitu sudah memiliki beberapa perusahaan yang setia menggunakan jasanya (S6). Selain itu, alternatif strategi tersebut ditunjang dari perusahaan yang dapat menjalin hubungan baik dengan para mitra dan pelanggannya (S9). Alternatif strategi tersebut diharapkan dapat mengantisipasi hilangnya pelanggan dan mitra karena mereka lebih memilih perusahaan pesaing.

\section{4) Alternatif Strategi WT}

1) Mengamati dan menganalisa perubahan dan inovasi yang dibuat pesaing

Dalam menghadapi persaingan dengan perusahaan-perusahaan sejenis yang baru muncul, serta menawarkan harga lebih murah dan armada yang lebih lengkap (T1, T2, T3) perusahaan perlu melakukan alternatif strategi yaitu mengamati dan menganalisa inovasi apa saja yang dibuat pesaing untuk menarik para pelanggannya. Terlebih perusahaan masih terbilang baru dalam bisnis ekspedisi logistik (W4). Dengan mengetahui apa saja trik dan inovasi pesaing, perusahaan dapat mengantisipasi perubahan apa yang harus dilakukan untuk dapat mengimbangi pesaimg.

2) Memberikan jaminan apabila terjadi kerusakan atau keterlambatan pengiriman

Kelalaian atas barang (W5) dapat membuat pelanggan kecewa bahkan kapok atas pelayanan perusahaan. Selain karena faktor manusia, kelalaian atau keterlambatan atas barang dapat juga terjadi karena adanya faktor cuaca yang buruk (T4). Hal tersebut dapat membuat pelanggan lebih memilih berpindah ke perusahaan pesaing. Untuk mengantisipasi terjadinya hal tersebut, Esa Logistik dapat melakukan alternatif strategi misalnya memberikan jaminan atau asuransi terhadap barang apabila terjadi kelalaian atas barang tersebut. Hal ini dilakukan sebagai sebuah perlindungan dan juga pengalihan risiko atas kehilangan, kerusakan dan bahkan keterlambatan pengiriman yang terjadi pada barang kiriman tersebut,.

d. Analisis QSPM

QSPM merupakan satu-satunya teknik analitis dalam literatur yang didesain untuk menentukan daya tarik relatif dari tindakan alternatif (David dan David, 2017:184). Teknik ini secara objektif mengindikasikan strategi alternatif yang terbaik di antara alternatif strategi lainnya. Tujuan analisis QSPM adalah menetapkan kemenarikan relatif dari strategi-strategi yang telah dipilih untuk menentukan strategi mana yang dianggap paling baik untuk diimplementasikan. Adapun perhitungan atas analisis matriks QSPM 
menghasilkan skor STAS yang dapat dilihat pada tabel 4 .

Tabel 4

Hasil Analisis QSPM PT Esa Jaya Global

\begin{tabular}{|c|c|c|}
\hline No. & Alternatif Strategi & $\begin{array}{c}\text { Sum Total } \\
\text { Atractiveness } \\
\text { Score } \\
\end{array}$ \\
\hline 1. & $\begin{array}{l}\text { Memperluas jaringan } \\
\text { distribusi }\end{array}$ & 5.724 \\
\hline 2. & $\begin{array}{l}\text { Memaksimalkan website } \\
\text { sebagai media promosi }\end{array}$ & 4.730 \\
\hline 3. & $\begin{array}{ll}\text { Meningkatkan } & \text { kualitas } \\
\text { layanan untuk menarik } \\
\text { pelanggan baru }\end{array}$ & 5.722 \\
\hline 4. & $\begin{array}{l}\text { Meningkatkan promosi } \\
\text { penjualan }\end{array}$ & 5.495 \\
\hline 5. & $\begin{array}{l}\text { Memperluas gudang } \\
\text { untuk mengantisipasi } \\
\text { meningkatnya pesanan }\end{array}$ & 4.063 \\
\hline 6. & $\begin{array}{l}\text { Melakukan pelatihan } \\
\text { karyawan }\end{array}$ & 4.464 \\
\hline 7. & $\begin{array}{l}\text { Menambah armada } \\
\text { transportasi }\end{array}$ & 3.678 \\
\hline 8. & $\begin{array}{l}\text { Memberi informasi } \\
\text { akurat apabila terjadi } \\
\text { kendala pengiriman }\end{array}$ & 4.084 \\
\hline 9. & $\begin{array}{l}\text { Membuat kontrak kerja } \\
\text { dalam waktu tertentu } \\
\text { dengan pelanggan dan } \\
\text { mitra }\end{array}$ & 5.728 \\
\hline 10. & $\begin{array}{l}\text { Mengamati dan } \\
\text { menganalisa perubahan } \\
\text { dan inovasi yang dibuat } \\
\text { pesaing }\end{array}$ & 4.560 \\
\hline 11. & $\begin{array}{lr}\text { Memberikan } & \text { jaminan } \\
\text { apabila terjadi kerusakan } \\
\text { barang } \\
\text { keterlambatan } \\
\text { pengiriman }\end{array}$ & 5.561 \\
\hline
\end{tabular}

Sumber: Data primer diolah, 2018

Berdasarkan tabel di atas, jumlah keseluruhan daya tarik (Sum Total Atractiveness Scores - STAS) dari masingmasing alternatif strategi yang diperoleh berdasarkan penilaian intuitif dan analitik dua (2) informan yang berkaitan langsung dengan perencanaan, implementasi dan evaluasi strategi di PT Esa Jaya Global yaitu Direktur dan Manajer Pemasaran.

Alternatif strategi yang memiliki nilai STAS tertinggi adalah alternatif strategi yang terbaik. Berdasarkan hasil analisis QSPM tersebut, maka prioritas strategi yang dapat digunakan adalah sebagai berikut: a. Prioritas 1 adalah melakukan kontrak kerja dengan pelanggan dan mitra perusahaan dengan STAS 5,728.

b. Prioritas 2 adalah memperluas jaringan distribusi dengan STAS 5,724.

c. Prioritas 3 adalah meningkatkan kualitas layanan untuk menarik pelanggan baru dengan STAS 5,722.

d. Prioritas 4 adalah memberikan jaminan apabila terjadi kerusakan barang atau keterlambatan pengiriman dengan STAS 5,561.

e. Prioritas 5 adalah meningkatkan promosi penjualan dengan STAS 5,495.

f. Prioritas 6 adalah memaksimalkan website sebagai media promosi dengan STAS 4,730.

g. Prioritas 7 adalah mengamati dan menganalisa perubahan dan inovasi yang dibuat pesaing dengan STAS $4,560.1$

h. Prioritas 8 adalah melakukan pelatihan karyawan dengan STAS 4,464.

i. Prioritas 9 adalah memberi informasi akurat apabila terjadi kendala pengiriman dengan STAS 4,084.

j. Prioritas 10 adalah memperluas gudang untuk mengantisipasi meningkatnya pesanan dengan STAS 4,063.

k. Prioritas 11 adalah menambah armada transportasi dengan STAS 3,678.

Hasil analisis QSPM tidak dapat mengindikasikan bahwa alternatif strategi yang memiliki skor lebih rendah merupakan alternatif strategi yang tidak penting dan tidak perlu dilaksanakan perusahaan. Hasil analisis QSPM menunjukkan prioritas alternatif strategi terbaik di antara beberapa alternatif strategi yang seluruhnya penting dan berpengaruh dalam mencapai keberhasilan perusahaan.

\section{KESIMPULAN DAN SARAN Kesimpulan}

Berdasarkan pembahasan yang telah diuraikan pada bab sebelumnya, kesimpulan dalam penelitian ini adalah sebagai berikut: 
1. Berdasarkan hasil analisis faktor internal pada PT Esa Jaya Global, terdapat 9 faktor kekuatan dan 6 faktor kelemahan yang dianggap paling berpengaruh terhadap perumusan strategi perusahaan. Faktor kekuatan utama tersebut antara lain: 1) Armada yang cukup untuk menunjang kegiatan ekspedisi, 2) SOP yang telah berjalan baik, 3) Layanan berkualitas dengan harga terjangkau, 4) Dapat menyesuaikan layanan dengan kebutuhan pelanggan, 5) Modal yang memadai, 6) Memiliki beberapa pelanggan setia yang selalu menggunakan jasa perusahaan, 7) Layanan update report yang akurat, 8) Memiliki website yang mudah diakses, dan 9) Mampu menjaga hubungan baik dengan pelanggan dan mitra. Adapun faktor kelemahan utama perusahaan adalah: 1) Promosi masih melalui mulut ke mulut, 2) Jumlah SDM yang masih terbatas dan belum memiliki banyak pengalaman, 3) Manajemen belum memiliki fasilitas untuk pengembangan dan pelatihan karyawan, 4) Perusahaan masih terbilang baru dalam bidang bisnis ekspedisi logistik, 5) Masih sering terjadi kelalaian saat pengiriman barang, dan 6) Keterbatasan gudang jika sedang dalam masa high season.

2. Berdasarkan hasil analisis faktor eksternal, terdapat 2 analisis peluang dan 4 analisis ancaman yang dianggap paling berpengaruh terhadap perumusan strategi perusahaan. Faktor analisis peluang utama tersebut adalah: 1) Pangsa pasar yang luas, dan 2) Dapat mengambil alih pekerjaan apabila pesaing mengalami overload. Sedangkan faktor ancaman utama perusahaan adalah: 1) Adanya pesaing dengan armada transportasi lebih lengkap, 2) Pesaing multinasional dengan harga lebih murah, 3) Munculnya perusahaan ekspedisi baru yang dibuat oleh perusahaan ritel, dan 4) Terkadang distribusi terkendala cuaca yang sulit ditebak.
3. Berdasarkan hasil analisis matriks IFE, EFE, dan matriks SWOT telah menghasilkan sebelas (11) alternatif strategi yang dapat dilakukan oleh PT Esa Jaya Global. Alternatif strategi tersebut selanjutnya dianalisis dengan teknik QSPM. Hasil analisis QSPM memberikan informasi atas prioritas atau alternatif strategi terbaik di antara yang paling baik yang dapat digunakan. Hasil analisis QSPM tersebut adalah: 1) Prioritas 1 adalah melakukan kontrak kerja dengan pelanggan atau mitra perusahaan dengan STAS 5,728. 2) Prioritas 2 adalah memperluas jaringan distribusi dengan STAS 5,724. 3) Prioritas 3 adalah meningkatkan kualitas layanan untuk menarik pelanggan baru dengan STAS 5,722. 4) Prioritas 4 adalah memberikan jaminan apabila terjadi kerusakan barang atau keterlambatan pengiriman dengan STAS 5,561. 5) Prioritas 5 adalah meningkatkan promosi penjualan dengan STAS 5,495. 6) Prioritas 6 adalah memaksimalkan website sebagai media promosi dengan STAS 4,730. 7) Prioritas 7 adalah mengamati dan menganalisa perubahan dan inovasi yang dibuat pesaing dengan STAS 4,560. 8) Prioritas 8 adalah melakukan pelatihan karyawan dengan STAS 4,464. 9) Prioritas 9 adalah memberi informasi akurat apabila terjadi kendala pengiriman dengan STAS 4,084.10) Prioritas 10 adalah memperluas gudang untuk mengantisipasi meningkatnya pesanan dengan STAS 4,063 dan 11) Prioritas 11 adalah menambah armada transportasi dengan STAS 3,678.

\section{Saran}

Berdasarkan serangkaian kegiatan perumusan strategi perusahaan yang telah dilakukan, PT Esa Jaya Global dapat mengambil tindakan terhadap alternatif strategi yang telah dihasilkan, antara lain:

a. Melakukan kontrak kerja dengan pelanggan dan mitra perusahaan untuk 


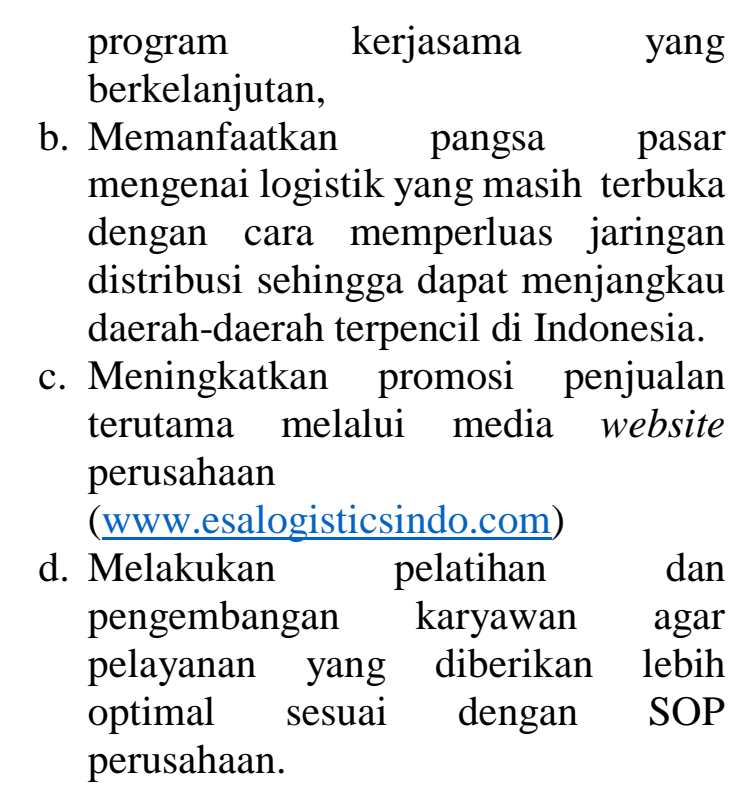

\section{UCAPAN TERIMA KASIH}

Penulis mengucapkan terima kasih kepada Pusat Penelitian Pengabdian Masyarakat (P3M) Politeknik Negeri Jakarta yang telah memberikan dana Bantuan Tugas Akhir Mahasiswa (BTAM) untuk pelaksanaan penelitian ini.

\section{DAFTAR PUSTAKA}

Buku:

Afrizal. 2014. Metode Penelitian Kualitatif: Sebuah Upaya Mendukung Penggunaan Penelitian Kualitatif dalam Berbagai Disiplin Ilmu. Jakarta: Rajagrafindo Persada.

Amir, M. Taufiq, 2016. Manajemen Strategik: Konsep dan Aplikasi. Jakarta: Rajawali Pers

David, Fred R. 2013. Strategic Management Concepts and Cases. England: Pearson education limited

David, Fred R dan Forest R David. 2016. Manajemen Strategik: Pendekatan Keunggulan Bersaing. Jakarta: Salemba Empat

Ghony, M Djunaidi dan Almanshur Fauzan. 2012. Metode Penelitian Kualitatif. Yogyakarta: Ar-ruzz media
Hunger, J David dan Wheelen, Thomas L. 2010. Manajemen Strategis. Yogyakarta: ANDI

Idrus, M. 2009. Metode Penelitian Ilmu Sosial: Pendekatan Kualitatif dan Kuantitatif. Jakarta: Erlangga

Nilasari, Senja. 2016. Manajemen Strategi Itu Gampang Untuk Orang Pemula \& Orang Awam. Jakarta: Laskar Group

Purnomo, Setiawan Hari dan Zulkieflimansyah. 2007. Manajemen Strategi, Sebuah Konsep Pengantar. Jakarta: Lembaga Penerbit Fakultas Ekonomi Universitas Indonesia

Rangkuti, Freddy. 2014. Analisis SWOT: Teknik Membedah Kasus Bisnis. Jakarta: Gramedia Pustaka Utama

Sarosa, Samiaji. 2012. Penelitian Kualitatif: Dasar-dasar. Jakarta: PT Indeks

Solihin, Ismail. 2012. Manajemen Strategik. Bandung: PT Gelora Aksara Pratama

Sugiarto, 2017. Metodologi Penelitian Bisnis. Jakarta: Andi

Sugiyono. 2017. Metode penelitian kuantitatif, kualitatif dan $R \& D$. Bandung: Alfabeta.

Sutarto. 2006. Dasar-Dasar Organisasi. Yogyakarta: Gajah Mada University Press.

Wahjono, Sentot Imam. 2008. Manajemen Tata Kelola Organisasi Bisnis. Jakarta: PT Indeks.

Yunus, Eddy. 2016. Manajemen Strategi. Yogyakarta: CV Andi Offset.

Yusuf, A. Muri. 2014. Metode Penelitian: Kuantitatif, Kualitatif, \& Penelitian Gabungan. Jakarta: Prenada Media Grup

Penelitian Terdahulu:

Agdi, Desinaya. 2016. Analisis Faktor Eksternal dan Internal dalam Formulasi Strategi Pemasaran Minyak Kelapa Sawit di PT MGG Jakarta. Depok

Gunawan, Dedi Septiadi. 2014. Analisis Lingkungan Eksternal dan Internal 
dalam Menyusun Strategi

Perusahaan (Studi Perencanaan

Strategi Komoditi Kelapa Sawit

pada PT Perkebunan Nusantara III

(Persero)). Malang

Rusly, Cindy Octavia. 2013. Pengelolaan dan Pengembangan Usaha Pada PT

Sariadi Wahana Jasa di Surabaya. Surabaya

Yudiaris, I Gde. 2015. Analisis Lingkungan Internal dan Eksternal dalam menghadapi Persaingan Bisnis pada CV Puri Lautan Mutiara.

Internet:

Setiawan, Sakina Rakhma Diah. 2018. "BI: Pertumbuhan Ekonomi Indonesia 5,1 Persen di Tahun 2017."

https://ekonomi.kompas.com/read/ 2018/02/02/173622526/bi-

pertumbuhan-ekonomi-indonesia51-persen-di-tahun-2017 diakses 4 maret 2018. 
